\title{
TYPOLOGY OF PUBLIC HOUSING IN TIRANA DURING THE ITALIAN OCCUPATION: CASE STUDY "LITTORIO VILLAGE" (LAPRAKË) AND "NEW TIRANA" NEIGHBOURHOOD
}

\author{
Oketa Boriçi $\left(\right.$ Hoxha) ${ }^{1 *}$, Florian Nepravishta ${ }^{1}$, Gjergj Thomai $^{1}$ \\ Polytechnic University of Tirana, Faculty of Architecture and Urbanism, Tirana, Albania; \\ ${ }^{1 *}$ Corresponding Author Oketa Boriçi (Hoxha), e-mail: oketahoxha@yahoo.com;
}

Received March 2021; Accepted April 2021; Published June 2021;

DOI: $\underline{\text { https://doi.org/10.31407/ijees11.323 }}$

\begin{abstract}
The Italian occupation has left numerous traces in Albania. It is worth mentioning the capital, Tirana, which has had significant development and progress from the influence of the Italian state in our country. This development has occurred in all areas, especially in urban planning and architecture. The Regulatory Plan of 1939-1943, created by Italian architects, left traces in the proposal and establishment of some neighbourhoods with collective housing concentrated in some regions of Tirana. This paper presents the maps and layout of these housing typologies of considerable importance for their created period. Tirana could not be excluded from the phenomena in other European countries during the same period, consisting mainly of the rapid population growth due to the migration of people from the countryside to the city and the increase of local and foreign labour force. This phenomenon led to increased demand in housing for this category of people and the need for new housing projects provided that they could accommodate as many people as possible. This paper presents neighbourhoods with collective housing of employees in Tirana, focusing on their location and plan's shapes. The study also describes the characteristics of these buildings and their organisation in the city's urban structure, highlighting the housing typologies. The comparison and confrontation of these projects (not all finalised in practice) with the popular collective housing in Europe after World War II is of particular importance. In Tirana, there is the presence of some typologies such as attached houses, block and linear collective houses. The main purpose of this paper is to identify the typology of collecte houses in Tirana during the Italian occupation. The study reveals the importance of repeating the same units inside a neighbourhood in order to rationalise the buildings to get better apartments and conditions of living. There is a strong connection between the typology of public housing and the number of families that can be accommodated in each neighbourhood's case study. The collective houses in "New Tirana" can shelter more families because of their characteristics such as the number of floors, utilisation of the land, organisation of plans with at least two apartments per floor.
\end{abstract}

Keywords: collective houses, Regulatory Plan, city-garden, public housing typology 